Mudalige Chamika Gajanayaka

\title{
News Media Regulation: A Mixed Membership Model Approach
}

Submitted for the LLB (Honours) Degree

Faculty of Law

Victoria University of Wellington

2013 


\section{Contents}

I Introduction 4

II News Media Regulation in New Zealand: The Status Quo 5

III The Law Commission's Recommendations 6

$\begin{array}{lll}\text { IV } & \text { First Principles } & 14\end{array}$

$\begin{array}{lll}V \quad \text { Recommended Model } & 19\end{array}$

VI Potential Objections to the Recommended Model 25

$\begin{array}{ll}\text { VII Conclusion } & 28\end{array}$

$\begin{array}{ll}\text { VIII Bibliography } & 30\end{array}$ 


\section{Abstract}

The traditional platform-centric approach to media regulation is no longer tenable with the distinct line between broadcast and print media being blurred by mainstream media combining text and video via the internet. To address platform convergence, the Law Commission recommends a universal news media regulator, the News Media Standards Authority, which encompasses broadcasters, the press and onlineonly providers. The Commission endorses a voluntary membership model with a range of incentives to entice entities to join. This paper will critique the efficacy of the Commission's incentives before undertaking a first principles analysis of news media regulation to illustrate the need for an element of compulsion in the membership model of the News Media Standards Authority. This paper argues that a mixed membership model, whereby a matrix of factors is used to determine the entities that will be required to join, is more appropriate for the News Media Standards Authority.

\section{Keywords}

Media

Regulation

Membership

Voluntary

Compulsory 


\section{Introduction}

News media plays a vital role in informing the public of news and opinion. Statutory privileges are granted to the news media to reflect its importance to society. Traditionally, the high costs associated with printing and broadcasting ensured that only organisations with sufficient means could disseminate information to a wide audience. Consequently, identifying and regulating those organisations was relatively simple. A platform dichotomy in regulation was justified because organisations disseminated their information through a single channel: print; television; or radio. Recent technological developments, namely the internet, have shattered those limits. Organisations are disseminating an array of information through multiple platforms and anyone with internet access can convey information to millions of people. The platform-centric regulatory model is being challenged by these developments.

Platform convergence places the future of media regulation in question. Three broad questions arise in addressing this issue:

- Firstly, should the news media be regulated separately from other parts of the media?

- Secondly, if separate regulation of the news media is justified, how should news media be defined?

- Thirdly, how should news media be regulated?

The Law Commission's (Commission) report, The News Media Meets 'New Media': Rights Responsibilities and Regulation in the Digital Age, ${ }^{1}$ looked to address these questions. The Commission provides a definition of news media ${ }^{2}$ and recommends confining the news media's statutory privileges to members of the Commission's proposed universal news media regulator, the News Media Standards Authority (NMSA) (Authority). ${ }^{3}$ NMSA will take a content-centric approach, rather than the current platform-centric approach, to media regulation in New Zealand.

The Commission recommends a voluntary membership model for NMSA. ${ }^{4}$ Entities $^{5}$ that meet the definition of news media will have the choice of being subject to NMSA's

\footnotetext{
${ }^{1}$ Law Commission The News Media Meets 'New Media': Rights, Responsibilities and Regulation in the Digital Age (NZLC R128, 2013).

2 At [3.63].

${ }^{3}$ At $[7.107]$

${ }^{4}$ At [7.132]

${ }^{5}$ The term "entity" will encompass organisations and individuals throughout this paper.
} 
jurisdiction. ${ }^{6}$ Joining is incentivised by statutory and non-statutory benefits exclusive to members. ${ }^{7}$ This paper will argue that NMSA should have a mixed membership model, rather than the proposed voluntary model, whereby certain entities will be required to join the Authority whilst others have the choice of joining.

This paper will firstly canvas the current media regulation landscape in New Zealand. Looking at the status quo will portray the regulatory gap that the Commission is attempting to fill with NMSA. ${ }^{8}$ The Commission's recommendations will then be outlined and critiqued, with the focus being on the attractiveness of the statutory incentives to potential members. Following this, a first principles analysis of news media regulation will be undertaken as the basis for this paper's view that NMSA needs an element of compulsion in its membership model. A matrix of factors will be used to determine the entities that should be required to join NMSA. Procedural matters relating to the Authority's governance and statutory formation will also be addressed. Finally, objections to having an element of compulsion in news media regulation will be rebutted.

\section{News Media Regulation in New Zealand: The Status Quo}

The Broadcasting Standards Authority (BSA), established in 1989, is a state regulatory body that regulates television and radio broadcasters; membership is mandatory. The Press Council (PC), established in 1972, is a self-regulatory body that regulates the press; membership is voluntary. The jurisdiction of these bodies is not confined to news. The BSA and PC reflect the traditionally distinct methods of delivering news and information: printing, encompassing newspapers and magazines; and broadcasting, encompassing television and radio.

Technological developments have enabled broadcasters and the press to deliver a range of content through multiple channels. The internet enables individuals to disseminate information at a scale and speed formerly reserved for large organisations with powerful distribution networks. The PC has adapted to convergence by extending its jurisdiction to incorporate members' websites. However, the BSA has not and does not have the power to similarly extend its jurisdiction unless the government amends the Broadcasting Act. ${ }^{9}$ Consequently, a gap in regulation for on-demand and online-only broadcaster content has emerged. The newly formed Online Media Standards Authority

\footnotetext{
${ }^{6}$ Law Commission, above $n$ 1, at [7.132]

${ }^{7}$ At [7.106]-[7.118].

${ }^{8}$ At [1.49]-[1.58].

${ }^{9}$ Broadcasting Act 1989, s 21.
} 
(OMSA) has jurisdiction over news and current events published online by its members but its effectiveness cannot yet be evaluated due to its infancy. ${ }^{10}$ With the same content being available on up to three different platforms, the current regulatory framework can result in a consumer having to make three separate complaints to three different regulatory bodies for an issue with the same content. Thus, a platform-centric approach to media regulation is no longer sustainable.

\section{The Law Commission's Recommendations}

The Law Commission does not view the extension of either or both the PC and BSA to fill the regulatory gap as a viable solution due to the two bodies being positioned at opposite ends of the regulatory spectrum; the BSA is statutorily-based and the Press Council is self-regulated by the press. ${ }^{11}$ A simple extension would entrench "the existing regulatory inconsistencies in the current environment". ${ }^{12}$ Instead, the Commission starts afresh and looks to define news media and how news media should be regulated in light of platform convergence. ${ }^{13}$

\section{A Defining News Media}

In the Commission's recommendations, an entity will be a part of the news media when: ${ }^{14}$

- a significant proportion of its publishing activities involves the generation and/or aggregation of news, information and opinion of current value;

- it disseminates information to a public audience;

- publication is regular and not occasional; and

- the publisher is accountable to a code of ethics and complaints process.

This definition will be altered in this paper's recommendations.

\footnotetext{
${ }^{10}$ Online Media Standards Authority "The Rules of the Online Media Standards Authority Incorporated" $<$ www.omsa.co.nz>.

${ }^{11}$ Law Commission, above $\mathrm{n}$ 1, at [7.20].

12 At $[7.20]$.

${ }^{13}$ At $[1.10]$.

${ }^{14}$ At [3.101].
} 
To address platform convergence, the Commission recommends a single regulatory body that oversees news, information and opinion of current value across all platforms. NMSA will effectively assume the responsibilities of the PC, BSA and OMSA in relation to news content.

NMSA will be self-regulated. ${ }^{15}$ A non-statutory foundation will be used for independence from the State (in contrast to the BSA but akin to the PC) and limits on industry involvement will maintain independence from the industry. The entities that meet the aforementioned news media definition can decide whether to be subject to the jurisdiction of NMSA. Those who subject themselves to the Authority's jurisdiction will enjoy a number of advantages compared to those that do not. The advantages include: ${ }^{16}$

- statutory privileges;

- a brand advantage from being subject to codes and standards;

- broadcasters having access to public funding;

- exemption from the Communication Tribunal's jurisdiction; and

- a mediation service.

The effectiveness of the proposed advantages for membership will be evaluated in turn to assess whether they are sufficient to induce potential members to voluntarily join.

C News Media Standards Authority: Efficacy of Incentives

$1 \quad$ Statutory privileges

The statutory privileges granted to the news media can be categorised as: legal exemptions to aid in gathering and disseminating information; and attendance rights to aid in accessing information. ${ }^{17}$

\section{(a) Legal exemptions}

Broadcasters and the press are exempt from Fair Trading Act 1986 liability for content that does not relate to the supply of goods and services or advertising. ${ }^{18}$ The exemption

\footnotetext{
${ }^{15}$ Law Commission, above $\mathrm{n}$ 1, at [7.170].

${ }^{16}$ At [7.106]-[7.118].

${ }^{17}$ At [2.7].
} 
is "drafted in such narrow terms"19 ${ }^{19}$ that information solely disseminated online ${ }^{20}$ or ondemand is not encompassed in the exemption. ${ }^{21}$ The purpose of the exemption is to "not encroach upon the freedom of the press". ${ }^{22}$ If the exemption was limited to NMSA members, non-members would be subject to civil or criminal liability for misleading and deceptive conduct ${ }^{23}$ or false representations. ${ }^{24}$ Avoiding civil or criminal liability will provide a material incentive for news media entities to join NMSA. However, it is difficult to see Parliament limiting the exemption to NMSA members because the potential for civil or criminal liability will chill the freedom of expression of nonmembers.

A "news medium", in relation to its news activities, is not defined as an "agency" under the Privacy Act and so is not subject to the information privacy regime of the Act, ${ }^{25}$ including its Information Privacy Principles (IPPs). ${ }^{26}$ The IPPs primarily address the collection, storage, access and use of personal information. ${ }^{27}$ The news media exemption recognises the "day to day practicalities of running a news organisation". ${ }^{28}$ The news media would struggle to "effectively"29 exercise its freedom of expression ${ }^{30}$ "if it were subject to the Privacy Act's principles" ${ }^{31}$ as the IPPs are "ill-aligned to the [news] media function". ${ }^{32}$ It is arguable whether Parliament would curtail the freedom of expression of non-members by restricting the exemption to NMSA members. If the restriction is imposed, being subject to the information privacy regime will be a material incentive for news media entities to join NMSA.

\footnotetext{
${ }^{18}$ Fair Trading Act 1986, s 15.

${ }^{19}$ Peter McLuskie "The FTA: Alternative to Defamation" [2001] NZLJ 96 at 97.

${ }^{20}$ Fair Trading Act, s 15(3)(b). The definition of "newspaper" in the Films, Videos, and Publications Classification Act 1993 does not include online content.

${ }^{21}$ Fair Trading Act, s 15(3)(a). The definition of "broadcasting" in the Broadcasting Act 1989, s 2, does not include on-demand content.

${ }^{22}$ (1 July 1986) 472 NZPD 2499.

${ }^{23}$ Fair Trading Act, ss 9-12.

${ }^{24}$ Fair Trading Act, ss 13-14.

${ }^{25}$ Privacy Act 1993, s 2(1)(b)(xiii). Section 2 of the Privacy Act defines "news medium" and "news activity".

${ }^{26}$ Privacy Act, s 6.

${ }^{27}$ Privacy Act, s 6.

${ }^{28}$ Elizabeth Longworth and Tim McBride The Privacy Act: A Guide (GP Publications, Wellington, 1994) at 259.

${ }^{29}$ Law Commission Review of the Privacy Act 1993: Review of the Law of Privacy Stage 4 (NZLC R123, 2011) at [4.26].

${ }^{30}$ New Zealand Bill of Rights Act 1990, s14.

${ }^{31}$ Law Commission, above n 29, at [4.26].

${ }^{32}$ At [4.26].
} 
(b) Attendance rights

News media reporters are granted access to certain criminal proceedings ${ }^{33}$ and Family and Youth Court cases ${ }^{34}$ that the public is generally not allowed to attend. Although members of the public may be discretionarily granted access, ${ }^{35}$ the news media have the benefit of a statutory right. Access is granted to "enable scrutiny of the proceedings on behalf of the public to ensure judges remain accountable". ${ }^{36}$

Accredited members of the Parliamentary Press Gallery enjoy access to special facilities throughout Parliament, as well as the exclusive right to report on proceedings in Parliament and select committees. ${ }^{37}$ The purpose of allowing access and reporting rights to a section of the media is to "provide specialised coverage and analysis of political and parliamentary news to the public". ${ }^{38}$

It is difficult to see Parliament restricting attendance rights to NMSA members and removing discretionary access as this would limit the ability of non-members to hold the Judiciary and Parliament to account. Historically, Parliament has not limited access to news media on the basis of an entity being subject to an external regulatory body such as the BSA or PC. If access is limited to NMSA members, this is likely to be a material incentive to mainstream news media that look to break news.

\section{Brand advantage}

The Commission believes that "belonging to the NMSA would be a mark of responsibility" 39 that would distinguish "a news medium from others" 40 and provide members with a "reputational advantage" 41 which members could kite mark their publications with. ${ }^{42}$

\footnotetext{
${ }^{33}$ Criminal Procedure Act 2011, s 198(1).

${ }^{34}$ Family Courts Act 1980, s 11A(1)(e); Family Proceedings Act 1980, s 159(2)(ca); Children, Young Persons, and Their Families Act 1989, s 166(1)(na); Care of Children Act 2004, s 137(1)(g); Social Workers Registration Act 2003, s 80(4)(g); Health Practitioners Competence Assurance Act 2003, s 97(4)(h).

${ }^{35}$ Family Courts Act, s 11A(1)(g); Family Proceedings Act, s 159(2)(d); Children, Young Persons, and Their Families Act, s 166(1)(o); Care of Children Act, s 137(1)(i); Social Workers Registration Act, s 80(4)(j); Health Practitioners Competence Assurance Act, s 97(4)(k).

${ }^{36}$ Law Commission, above $\mathrm{n} 1$, at [2.8].

${ }^{37}$ Rules of the Parliamentary Press Gallery 2011, r 14.

${ }^{38}$ New Zealand Parliament "The Parliamentary Press Gallery” (3 May 2013) <www.parliament.nz>.

${ }^{39}$ Law Commission, above $n$ 1, at [7.111].

${ }^{40}$ At [7.111].

${ }^{41}$ At [7.111].

${ }^{42}$ At [7.113].
} 
A reputational advantage in a regulatory context has two sides: the member and the regulatory body, both of which must have a good reputation for an advantage to arise. Reputation is built over time and cannot simply be attained by attaching a logo to one's publication or notionally joining a regulatory body. Furthermore, consumers do not rely on regulatory body decisions as an indicator of a programme having a good reputation. For example, Campbell Live, 3 News and One News were the three most complained about programmes in $2012,{ }^{43}$ but are still among the country's most viewed television programmes. ${ }^{44}$ Moreover, entities that are currently subject to an external regulatory body, such as the BSA or PC, do not kite mark their publications to indicate membership. Thus, NMSA members are unlikely to view kite marking their publication to indicate membership as a material benefit.

The Commission's view of brand advantage may be confined to the idea that, everything else being equal, the public is more likely to consume news from a source that has an established formal complaints system than one that does not. However, since fewer than two in five people know of the existence of news media standards, an entity is unlikely to gain more readers or viewers from being subject to the standards of a regulatory body. ${ }^{45}$ The public is more likely to give weight to the reputation of an agency that has upheld high journalistic standards for an extended period of time. Organisations such as the British Broadcasting Corporation in Britain, the Australian Broadcasting Corporation in Australia and Radio New Zealand in New Zealand would embody such a sentiment. ${ }^{46}$ It is also uncertain how much new media actually relies on reputation. For example, some may in fact rely on the contrary: a niche audience that looks to them for a unique and untrammelled perspective on news and current affairs, rather than for ethically sound journalism or for having the possibility to complain to a regulatory body.

Thus, the "brand advantage" may not be a strong incentive for potential members to join NMSA, particularly in its early stages when its efficacy is unproven.

\section{$3 \quad$ Public funding}

Broadcasting and production companies can apply for funding from the Broadcasting Commission $(\mathrm{BC})$ to produce content. Production companies are the predominant

\footnotetext{
43 Broadcasting Standards Authority BSA Annual Report 2012 (Broadcasting Standards Authority, Wellington, 2012) at 58.

${ }^{44}$ Regan "TV Ratings: 6 September 2013” (7 September 2013) Throng <www.throng.co.nz>.

45 Big Picture Marketing Strategy and Research Public Perception of News Media Standards and Accountability in New Zealand (Big Picture Research, Auckland, 2012) at [6.1].

${ }^{46}$ Law Commission, above $\mathrm{n}$ 1, at [7.111].
} 
recipients of funding. ${ }^{47}$ Funding for any programme is conditional upon the production company being contracted with a broadcaster. ${ }^{48}$ The Law Commission recommends a further stipulation that for a production company to be eligible to receive funding for news programmes, the broadcaster that the production company is contracted to must be a NMSA member. ${ }^{49}$

The stipulation is likely to encourage broadcasting companies to join the Authority in fear of production companies contracting with other broadcasters that are NMSA members in order to secure funding. However, this incentive only affects broadcasters, which in itself is a small portion of the news media; the press will not be affected. In 2012 , the BC provided over $\$ 85,000,000$ of funding for television programmes. Documentaries accounted for over $\$ 21,000,000$ of funding but no news or current affairs programmes were funded. ${ }^{50}$ Despite the relatively wide definition of news being adopted by the Law Commission, ${ }^{51}$ not all documentaries would be deemed news; nor would other genres such as special interest and drama. Notwithstanding definitional discrepancies between the Law Commission and BC, the funding levels for news programmes may be overstated by the Law Commission.

The importance, or lack thereof, of BC funding to an entity depends on the portion of its content being news related and the portion of that news related content being publicly funded. Nonetheless, having the option of seeking public funding will be an incentive for a production company to contract with a broadcaster that is a member of NMSA, and consequently an incentive for a broadcaster to become a member of NMSA.

\section{$4 \quad$ Communication regime jurisdiction}

In response to the Law Commission's Ministerial Briefing paper on harmful digital communications, ${ }^{52}$ the government will adopt a two-step approach to dealing with harm caused by harmful digital publications. ${ }^{53}$ Complaints will initially be adjudicated by an approved agency (Agency). ${ }^{54}$ Subsequently, appeals can be made to the District Court. ${ }^{55}$

\footnotetext{
${ }^{47}$ Law Commission, above n 1 , at [7.115].

${ }^{48}$ At [7.115].

${ }^{49}$ At [7.117].

${ }^{50} \mathrm{NZ}$ On Air "Funding Decisions" <www.nzonair.govt.nz>.

${ }^{51}$ Law Commission, above n 1, at [7.40].

52 Law Commission Harmful Digital Communications: The adequacy of the current sanctions and remedies (NZLC Ministerial Briefing Paper, 2012).

${ }^{53}$ Cabinet Social Policy Committee Harmful Digital Communications: Cabinet Social Policy Committee Paper.

${ }_{55}^{54}$ At [38].

${ }^{55}$ At [45].
} 
The Commission recommends exempting NMSA members from the jurisdiction of this communications regime. $^{56}$

Not being subject to the communications regime is arguably not a material incentive. To make a complaint to the Agency, the complainant must have exhausted all other avenues of complaint. With many websites having internal censorship and moderation systems as well as in-house complaint procedures that deal with harmful contributors, the portion of complaints that reach the Agency could be relatively low. Additionally, large amounts of content consumed by New Zealanders originate from overseas where the regime has no jurisdiction. ${ }^{57}$ Remedially, the Agency and District Court cannot order damages. ${ }^{58}$

Conceptually, it is not a benefit for an entity to avoid the jurisdiction of the communications regime. NMSA's proposed standards and codes are stricter than the principles set out for the regime. ${ }^{59}$ Under NMSA, a member has to meet standards of accuracy, correction of error, separation of fact and opinion, balance, fairness and privacy. ${ }^{60}$ The communication regime's principles broadly cover these factors. However, in contrast to the regime, the Authority's standards will be tailored to different news mediums to ensure comprehensive coverage and methods of gathering information will also be subject to scrutiny. ${ }^{61}$ On a practical note, several of the regime's principles are aimed at addressing behaviour that the news media is not engaged in, such as inciting harmful messages or publishing menacing material. Thus, the news media may be indifferent to being subject to these principles because they are unlikely to breach them.

\section{$5 \quad$ Mediation service}

NMSA will provide a mediation service to encourage settlement without litigation. Mediation services by media regulatory bodies have been favourably received overseas, such as the Press Complaints Commission's mediation service in the United Kingdom. ${ }^{62}$ However, regardless of the availability of a mediation service, it is contingent on both parties voluntarily engaging in mediation. Thus, if entities do not partake in mediation, the service will not be an incentive to join NMSA.

\footnotetext{
${ }^{56}$ Law Commission, above $\mathrm{n}$ 1, at [7.114].

${ }^{57}$ Cabinet Social Policy Committee, above n 53, [59].

${ }^{58}$ At [56].

${ }^{59}$ Law Commission, above $\mathrm{n}$ 1, at [7.46]-[7.62].

${ }^{60}$ At [7.57]. Standards of good taste and decency will still be administered by the BSA, at [7.44].

${ }^{61}$ Law Commission, above n 1, at [7.60]-[7.61].

${ }^{62}$ Philip Ward "Press Regulation - the Debate" (House of Commons Library Note SN/HA/6357, 2012) at [2.6].
} 
Media ownership in New Zealand is highly concentrated. Fairfax Media New Zealand and APN News Media control around 90 per cent of newspaper publications ${ }^{63}$ and Sky Television has a monopoly on pay television with only three main competitors in freeto-air television. ${ }^{64}$ The efficacy of NMSA will ultimately hinge on these organisations voluntarily joining the Authority. If they do not join, the whole regulatory system will be undermined by a large section of the news media being unregulated. Voluntary membership raises concerns about the leverage large media organisations may have over the establishment of the Authority and its on-going operations.

The threat of not being a member is the primary form of leverage that entities have over NMSA. An entity can be a non-member of NMSA by not joining the Authority in the first instance or by withdrawing subsequent to joining, either by breaching the proposed five year membership contract or not renewing the contract after five years. Nonmembers can continue to publish as they please, as long as they are in line with the law. ${ }^{65}$ The proposed five year contracts between the Authority and its members somewhat mitigates the threat of member withdrawal upon an adverse decision, particularly when contract termination will be limited to situations where an entity merges, is acquired or becomes insolvent. ${ }^{66}$ Despite this, with the Authority being principally funded by its members, ${ }^{67}$ there is an opportunity for the news media industry to unduly influence, or at least be perceived to unduly influence, NMSA with the threat of withdrawal materially impacting the Authority's funding, depending on the entity that withdraws.

Whilst NMSA is being formed, large entities could premise their membership on certain conditions, such as specific individuals being a part of the governance structure or even that the Authority's codes and standards are outlined in a manner that suits them. For example, in the United Kingdom the most powerful press organisations are pressuring parliament to set up a press regulator that is self-regulated by the industry, rather than the approach agreed to by parliament to have an element of independent regulation, following the Leveson Inquiry. ${ }^{6}$

\footnotetext{
${ }^{63}$ Bill Rosenberg "News Media Ownership in New Zealand: Who Owns What?" (13 September 2008) $<$ www.converge.org.nz>.

${ }^{64}$ Bill Rosenberg, above n 63.

${ }^{65}$ Law Commission, above $\mathrm{n} 1$, at [7.168].

${ }^{66}$ At [7.95].

${ }^{67}$ At [7.93].

68 Hacked Off "What's wrong with the press bosses' latest regulation proposal?" (12 July 2013) $<$ www.hackinginquiry.org>; The Rt Hon Lord Justice Leveson Report of An Inquiry into the Culture, Practice and Ethics of the Press (The Stationary Office, London, 2012).
} 
Once formed, adjudicating complaints will be one of NMSA's primary functions. The possibility of withdrawal could influence the Authority's decision making. In 2011, Sun Media, Canada's largest newspaper publisher withdrew all its publications from the Ontario Press Council (OPC) because of the Council's "politically correct mentality". 69 The OPC is a voluntary self-regulatory body, ${ }^{70}$ where media organisations may withdraw by simply giving a year's notice of such intent. ${ }^{71}$ The withdrawal of Sun Media caused the Council to make "significant budget cuts". ${ }^{72}$ There were no legal ramifications for Sun Media from the withdrawal. In comparison, the membership regime for NMSA is more concrete than the OPC's with five year contracts and limited opportunities for withdrawal once contracted. However, an entity not renewing its membership upon the contract expiring would, depending on the size of the entity that withdraws, cause similar levels of disruption to NMSA.

News media proprietors in New Zealand may also share the sentiment of Richard Desmond when he withdrew one of the Britain's largest newspaper publishers, Northern \& Shell, from the Press Complaints Commission. ${ }^{73}$ Desmond indicated that he "no longer saw value in remaining in the regulatory system", and that Northern \& Shell could "operate the principles of self-regulation themselves". ${ }^{75}$

\section{First Principles}

The right to freedom of expression is protected in New Zealand by s 14 of the Bill of Rights Act. ${ }^{76}$ NMSA is placing restrictions on the right to freedom of expression by setting standards that members must follow ex-ante and imposing penalties for breaching standards ex-post. Such restrictions need to be "demonstrably justified in a free and democratic society" 77 because the proposed mixed membership model will be statutorily-based and so "prescribed by law" ${ }^{78}$

\footnotetext{
${ }^{69}$ Allison Jones "Sun Media ditches press council, citing issues with 'political correctness"' The Toronto Star (13 July 2011) <www.thestar.com>.

${ }^{70}$ Ontario Press Council "Constitution" (2010) <www.ontpress.com>, at art II.

${ }^{71}$ At art II(B)(2).

72 Don McCurdy "Executive Director's 2012 Report" Ontario Press Council (5 January 2013) $<$ www.ontpress.com>.

${ }^{73}$ Ian Burrell "Desmond withdraws his titles from press complaints regulation" The Independent (12 January 2011) <www.theindependent.co.uk>.

${ }^{74}$ Ian Burrell, above n 75.

${ }^{75}$ Ian Burrell, above n 75.

${ }^{76}$ New Zealand Bill of Rights Act, s 14.

${ }^{77}$ New Zealand Bill of Rights Act, s 5.

${ }^{78}$ New Zealand Bill of Rights Act, s 5.
} 
For regulation to be "demonstrably justified in a free and democratic society", 79 the limits placed on the right to freedom of expression need to be proportionate. ${ }^{80}$ The rationales for freedom of expression will be outlined before defining its scope in relation to news. This will be contrasted with the restrictions placed on freedom of expression by a statutory-based regulator compelling some news media entities to be regulated. Additionally, other professions that mandatorily regulate its practitioners will be compared and contrasted with news media.

\section{A Freedom of Expression}

\section{$1 \quad$ Rationale for freedom of expression}

The three primary reasons for freedom of expression are: discovering the truth; individual autonomy and self-fulfilment; and a functioning democracy. ${ }^{81}$ Ancillary rationales include providing a check on public power and encouraging social debate through communication rather than violence. ${ }^{82}$

Discovering the truth is based on the concept of a "marketplace of ideas" "competing views of the truth clash together in open debate" ${ }^{84}$ to help people in their search for the truth. Restrictions should not be placed on the marketplace because truth is not absolute and restricting expression on the basis of falsity amounts to the restrictor implying there is an absolute truth, or an absolute falsity. ${ }^{85}$ An objectively correct or right view may only be attained when both sides of a view are in the marketplace and the contributors are forced to validate or defend their views. ${ }^{86}$

Individual autonomy is based on the idea that the right to freely generate and share views for discussion and criticism is vital to one's intellectual and spiritual development. ${ }^{87}$ However, it is arguable whether an unfettered freedom of expression fosters self-fulfilment, particularly when conflicting rights, such as rights to decency in

\footnotetext{
${ }^{79}$ New Zealand Bill of Rights Act, s 5.

${ }^{80}$ Claudia Geiringer and Steven Price "Moving from Self-Justification to Demonstrable Justification - the Bill of Rights and the Broadcasting Standards Authority" in Jeremy Finn and Stephen Todd Law, Liberty, Legislation (LexisNexis, Wellington, 2008) 295 at 319.

${ }^{81}$ Wojciech Sadurski Freedom of Speech and Its Limits (Kluwer Academic Publishers, Dordcrecht (The Netherlands), 1999) at 7-9.

${ }^{82}$ Geiringer and Price, above n 80 , at 321.

${ }^{83}$ Eric Barendt Freedom of Speech (Oxford University Press, Oxford, 1985) at 8-23.

${ }^{84}$ Steven Price "The BSA and the Bill of Rights: A Practical Guide" (Broadcasting Standards Authority, Wellington, 2012) at 9.

${ }^{85}$ Barendt, above $\mathrm{n} 83$, at 8.

${ }^{86}$ At 9.

${ }^{87}$ At 14 .
} 
relation to the expression of pornography, ${ }^{88}$ may be of equal or greater importance relative to that expression. ${ }^{89}$ It may be viewed as one of a bundle of rights that are generally required for holistic self-fulfilment, ${ }^{90}$ whereby other rights in the bundle take priority in some instances.

Freedom of expression is imperative to a fully functioning democratic state for two reasons. Firstly, free expression is necessary to provide constituents with the information they need to carry out their democratic mandate. Secondly, free expression provides transparency to keep public representatives accountable to their actions. ${ }^{91}$ If such expression is constrained, there is a risk that the public will not be in a position to carry out the said purposes. For a democracy to be robust, these purposes must be fulfilled.

\section{$2 \quad$ Scope of freedom of expression}

Like any marketplace where all products are not of equal value, all expression is not of equal value. The extent to which expression furthers the aforementioned rationales will dictate its importance in the marketplace. ${ }^{92}$ The more a type of expression fulfils those purposes, the greater the justification needs to be to restrain that type of expression.

Political speech, which is a subset of news, is given a "preferred position" 93 by academics and the courts due to its democratic importance. It "encourages a wellinformed and politically sophisticated electorate [that is] able to confront government on more or less equal terms." 94 News provides an "exchange of information and ideas on matters relevant to the organisation of the economic, social and political life of the country". ${ }^{95}$ Moreover, such expression provides diverse views to the marketplace of ideas to help ascertain the truth as well as aiding in the self-development of one's intellect and spirituality. ${ }^{96}$ This can be contrasted with hate speech and pornography which do little to further the aforementioned rationales for freedom of expression and thus warrant less protection. ${ }^{97}$

\footnotetext{
${ }^{88}$ Barendt, above $\mathrm{n} 83$, at 16 .

${ }^{89}$ At 15.

90 At 15 .

${ }^{91}$ Frederick Schauer Free Speech: A Philosophical Enquiry (Cambridge University Press, Cambridge, 1982) at 36.

92 Sarduski, above $\mathrm{n} 81$, at 38 .

93 Barendt, above $\mathrm{n} 83$, at 146.

${ }^{94}$ At 146.

95 Campbell v MGN Ltd [2004] 2 AC 457 (HL) at [148].

${ }^{96}$ Barendt, above n 83, at 146.

${ }^{97}$ Price, above $\mathrm{n} 84$, at 10 .
} 
Due to its importance to individuals and society, news will be given a wide scope of protection under the right to freedom of expression. The strength of this protection will be analysed to ascertain whether regulation of the right will "demonstrably justified". ${ }^{98}$

\section{B Restricting Freedom of Expression}

The news media furthers the aforementioned rationales for the right to freedom of expression. This creates a paradox in that the news media must be allowed to carry out its function freely and without undue influence but at the same time, with the scope of the right being so wide, there is a high chance that the rights of individuals, such as one's right to privacy, and the rights of the general public will be breached. The priority to be given to respective rights when a conflict arises must be assessed contextually. A regulator can arguably facilitate this analysis more effectively than the market. "There is a general agreement that free speech is not an absolute [right]" $" 99$ because of such inconsistencies.

The news media "builds a bridge between public opinion and public policy."100 This is magnified in New Zealand by the concentration in media ownership alluded to earlier. ${ }^{101}$ A distinct minority wields the power to influence the majority. Consequently, it is "almost universally accepted that there are circumstances in which free speech and a free press should be subject to restriction". ${ }^{102}$

As a result of the unique and pervasive power held by the news media, a social responsibility to the public that the power will be used in line with individual and public interests arises. ${ }^{103}$ This responsibility reflects the special privileges and exemptions afforded to the news media on the basis that they were the only ones with the means to fulfil some of society's most important needs. ${ }^{104}$ Critics of a social responsibility theory think the public should bear the responsibility of protecting their own interests by analogising the news media to other industries that sell "a manufactured product at... [the consumer's] own risk". ${ }^{105}$ With new media providing an ever-increasing amount of

\footnotetext{
${ }^{98}$ New Zealand Bill of Rights Act, s 5.

${ }^{99}$ Schauer, above n 91, at 134.

${ }^{100}$ The Hon R Finkelstein QC Report of the Independent Inquiry into the Media and Media Regulation (Report to the Minister for Broadband, Communications and the Digital Economy, Canberra, 2012) at [2.53] [Finkelstein Report].

${ }^{101}$ Rosenberg, above n 63.

${ }^{102}$ Finkelstein Report, above n 100, at [2.47].

${ }^{103}$ William Hocking Freedom of the Press: A Framework of Principle (The University of Chicago Press, Chicago, 1947).

${ }^{104}$ Hocking, above n 103.

105 Fred Siebert, Theodore Peterson and Wilbur Schramm Four Theories of the Press (University of Illinois Press, Illinois, 1956) at 73.
} 
news and news commentary, it could be said that news media should not be burdened with a social responsibility. However, rather than being a substitute for traditional news media, new media complements the traditional news media because new media still relies on the traditional news media for the primary information that they then colour with opinion and commentary. ${ }^{106}$ Therefore, burdening the news media with a social responsibility is still justified.

The standards and codes that news media have generally had to abide by relate to: accuracy; balance; fairness; good taste; and privacy. The BSA upheld ten per cent of complaints 2011/2012. ${ }^{107}$ This is a marked decrease from 2009/2010 and 2010/2011 where over 29 and 23 per cent of complaints were upheld, respectively. ${ }^{108}$ The PC has upheld over 49, 44, and 45 per cent of complaints it determined in 2010, 2011 and 2012, respectively. ${ }^{109}$ Although these figures concern entertainment complaints as well as news complaints, it is evident that the news media does cause harm that is outside its right to freedom of expression. If there was no external regulator and freedom of expression was absolute, the news media could cause harm without an avenue of recourse for victims.

\section{Other Professions}

Many professions demand that its professionals be mandatorily subject to a regulatory body that imposes standards of practice and an ethical code. For example, in New Zealand the New Zealand Law Society regulates legal professionals, the Medical Council of New Zealand regulates medical professionals and the New Zealand Institute of Chartered Accountants regulates accountants. These professions are regulated for three broad reasons: market failure; public interest; and private interest. ${ }^{110}$

The New Zealand Law Society, ${ }^{111}$ the Medical Council of New Zealand ${ }^{112}$ and the New Zealand Institute of Chartered Accountants ${ }^{113}$ are all statutorily-based, which gives weight to this paper's recommendation for NMSA to be statutorily-based. The harm caused by the news media can be just as severe as other substandard professional

\footnotetext{
${ }^{106}$ Big Picture Marketing Strategy and Research, above n 45, at [3.2].

${ }^{107}$ Broadcasting Standards Authority, above n 45, at 57.

108 At 57.

109 New Zealand Press Council $40^{\text {th }}$ Report of the New Zealand Press Council (New Zealand Press Council, Wellington, 2012) at 13.

${ }^{110}$ Nuno Garoupa "Regulation of Professions in the US and Europe: A Comparative Analysis (April 2004) The Berkeley Electronic Press <www.law.bepress.com> at 4.

${ }^{111}$ Lawyers and Conveyancers Act 2006, pt 4.

${ }^{112}$ Health Practitioners Competence Assurance Act 2003.

${ }^{113}$ New Zealand Institute of Chartered Accountants Act 1996, ss 4-8.
} 
service. A tarnished reputation, trial by media or views formed on biased or inaccurate news not only affects individuals, but wider society. Moreover, a key distinction between the news media and other professions is that certain qualifications are a prerequisite to practice as a lawyer, doctor or accountant, whereas anyone can be a part of the news media with recent technological advancements. This provides more reason for the news media to be regulated because with no qualification requirements, the opportunity to teach proper standards and ethics during the qualification is not present like it is with other professions.

\section{Recommended Model}

This paper recommends a mixed membership model for NMSA whereby some entities will be required to join the Authority whilst others can voluntarily join. A matrix of factors will be balanced by an independent panel to determine the entities that will be required to join NMSA. The Authority will be statutorily-based to provide enforceability in applying the matrix of factors. A definition of news media will also be adopted to restrict the entities that can voluntarily join NMSA. The Authority will be subject to judicial review because it is carrying out a public function and is statutorilybased. ${ }^{114}$ The efficacy of the matrix can be judged by whether it encompasses the entities that should have their freedom of expression regulated and omitting those that should not.

\section{A Statutory Basis}

The Authority will be established by statute to ensure enforceability when requiring certain entities to join NMSA. ${ }^{115}$ The Authority will need to operate at arm's length from the State to avoid perceptions of political influence. Similarly, the Authority will need be independent of the news media industry to avoid perceptions of it being selfserving to the industry it is regulating.

A minimalist statutory basis for the Authority will ensure independence whilst providing sufficient power to carry out its functions. A statutory model similar to that of the New Zealand Institute of Chartered Accountants will be used, as initially recommended by the Law Commission in its Issues Paper. ${ }^{116}$

\footnotetext{
${ }^{114}$ The statute forming NMSA will expressly recognise that all its decisions are subject to judicial review. ${ }^{115}$ Law Commission The News Media Meets 'New Media': Rights, Responsibilities and Regulation in the Digital Age (NZLC IP27, 2011) at [6.119].

${ }^{116}$ At [6.118]-[6.123].
} 
The Irish Press Council provides a good example of a statutorily-based media regulatory body that operates at arm's length from the State. The Defamation Act, ${ }^{117}$ which forms the Irish Press Council, adopts a minimalistic approach. It leaves matters such as the code of standards, ${ }^{118}$ funding calculations ${ }^{119}$ and handling complaints ${ }^{120}$ to the Press Council. The Danish Press Council ${ }^{121}$ also provides a good example of leaving the regulator to determine the substance of regulation whilst still being formed by statute. ${ }^{122}$ However, neither the Irish Press Council nor the Danish Press Council has a mixed membership model; the Irish Press Council is wholly voluntary and the Danish Press Council is wholly mandatory. ${ }^{123}$

\section{B Applying the Matrix}

There is potential for NMSA's governance to be adversely affected by agency issues. Those who run the Authority are incentivised to have more members so that funding and regulation coverage is greater. Therefore, it is important to have an independent governance structure that looks to first principles when applying the matrix.

This paper will adopt the structure recommended by the Law Commission for the governance of the panel that will apply the matrix of factors. ${ }^{124}$ Independent appointments combined with a mix of people from a legal, media and public background ensures that the perspectives of all relevant stakeholders are considered. ${ }^{125}$ Fixed terms for members with limited scope for removal will mitigate outside pressures affecting decisions. ${ }^{126}$ The onus will be on the panel to prove that an entity is required to join NMSA with structured reasoning in balancing the matrix of factors. This panel will also carry out NMSA's adjudication function but the management of the Authority will be separate. $^{127}$

\footnotetext{
${ }^{117}$ Defamation Act 2009 (Ireland).

${ }^{118}$ Defamation Act, sch 2 s 10.

${ }^{119}$ Defamation Act, sch 2 s 7.

${ }^{120}$ Defamation Act, sch 2 s $8(1)$.

${ }^{121}$ Media Liability Act 1998 (Denmark), s 41.

${ }^{122}$ Lara Fielden "Regulating the Press: A Comparative Study of International Press Councils" (Reuters Institute for the Study of Journalism, Oxford, 2012) at 52.

${ }^{123}$ At 52 .

${ }^{124}$ Law Commission, above $n$ 1, at [7.30]-[7.34].

125 At [7.31].

${ }^{126}$ At [7.362].

127 At [7.33].
} 
Numerous submitters to the Law Commission's Issues Paper looked favourably upon a certain level of compulsion to NMSA's jurisdiction. ${ }^{128}$ In its Issues Paper, the Commission contemplated the following criteria to determine compulsory membership: ${ }^{129}$

- that the publication of news, and commentary on the news, is a significant part of the organisation's enterprise;

- that the publication is to the public or a section of the public;

- that the publication is regular, rather than occasional;

- that the publication is undertaken as a business or commercial activity; and

- that the coverage of the news by the organisation is broad and general rather than confined to narrow specialisations.

In 2010, Matthew Dearing recommended extending the BSA's jurisdiction to the programming content provided by broadcasters via the internet. ${ }^{130}$ The extension would only be made to "Internet Broadcasters". 131 To determine what an "Internet Broadcaster" is, ${ }^{132}$ Dearing proposed a set of criteria which included factors such as: ${ }^{133}$

- Is the broadcaster a large commercial organisation (i.e. does it have a large budget derived from advertising revenue)?

- Does the broadcaster have paid staff (e.g. reporters, marketing team)?

- Is the broadcaster a reputable source of news and factual information that a large part of the New Zealand public trust?

- How large is the broadcaster's audience $(10$ or 100,000$)$ ?

After considering the two sets of factors above, the matrix will adopt the following two holistic factors:

- a publication or programme's influence on the public; and

- the commerciality of the publisher or broadcaster.

\footnotetext{
${ }^{128}$ Law Commission, above n 115, at [6.109]-[6.115].

${ }^{129}$ At [6.113].

${ }^{130}$ Matthew Dearing “Taming the Wild West - A Framework for Regulating and Applying Broadcasting Standards to Internet Content in New Zealand" (LLM Dissertation, Victoria University of Wellington, 2010).

${ }^{131}$ At 41 .

132 At 41 .

${ }^{133}$ At 41 .
} 
The factors will have a range of sub factors for the panel to consider. Public influence and commerciality will need to be balanced; a non-commercial entity may still be required to join the Authority because of its influence on the public and a commercial entity may be required to join despite not materially influencing the public. Under the matrix, all entities that are currently regulated by the BSA or PC will be required to join NMSA. Several new media entities, namely Scoop.co.nz, ${ }^{134}$ Whale Oil Fish Hooked ${ }^{135}$ (Whale Oil) and Kiwiblog, ${ }^{136}$ will also be required to join due to their influence on the public, rather than their commerciality. Trade publications, such as LawTalk, ${ }^{137}$ the New Zealand Law Society's fortnightly magazine, have a material influence on the public and so should also be required to join NMSA.

\section{$1 \quad$ Influence on the public}

A publication or broadcast's influence on the public is determined by the cross section of the public it is received by, the content it publishes and, to a lesser extent, the frequency of dissemination. The greater the audience, the greater the harm if the publication or broadcast is substandard. Likewise, the more frequent the publication or broadcast, the greater the likelihood that standards will be breached and harm occurs.

Base figures will be used to bring entities to the attention of the panel but these figures will not limit the panel's ability to consider other entities for compulsory membership. The true assessment of an entity's influence on the public should be qualitative rather than quantitative because dealing solely with figures can be deceiving. Content can influence the public even if it is received by a small audience if that audience comprises influential people like politicians and celebrities. Likewise, a publisher or broadcaster that only produces content once a year can be influential if that content is consumed by many people. Thus, the relevance of audience numbers and frequency of dissemination is not about whether or not harm can occur, but the probability of harm occurring.

The base figures should reflect the public's trust and reliance on the source of the content: the higher the trust and reliance, the lower the threshold should be. Over 78 per cent of New Zealanders use television, newspapers or newspaper websites as their main source of news. ${ }^{138}$ In terms of reliance, 84 per cent of New Zealanders rely on the aforementioned channels for validity when faced with conflicting information from

\footnotetext{
${ }^{134}$ Scoop.co.nz "Introducing Scoop.co.nz" <www.scoop.co.nz>.

${ }^{135}$ Cameron Slater "About” Whale Oil Beef Hooked $<$ www.whaleoil.co.nz $>$.

${ }^{136}$ David Farrar "About Kiwiblog" Kiwiblog <www.kiwiblog.co.nz $>$.

${ }^{137}$ New Zealand Law Society "LawTalk" <www.lawsociety.org.nz>.

${ }^{138}$ Big Picture Marketing Strategy and Research, above n 47, at [3.2].
} 
different sources. ${ }^{139}$ Consequently, the thresholds for television, newspapers and newspaper websites should be lower than the thresholds for other news sources, such as small news websites, who are only relied on by eight per cent of the public, to ensure they are more likely to be required to join.

The Australian Independent Inquiry into the Media and Media Regulation ${ }^{140}$ identified 3,000 units of print per issue or a website having a minimum of 15,000 hits per annum as thresholds for being subject to regulation. ${ }^{141}$ It is admitted that these "numbers are arbitrary, but a line must be drawn somewhere". ${ }^{142}$ New Zealand's smaller size dictates lower thresholds. This paper recommends 1,500 prints per issue, 8,000 unique website hits per annum and 20,000 unique viewers per annum as the base figures to bring an entity to the attention of the panel. These are not strict limits; the panel may require any entity that materially influences the public to join NMSA.

By way of illustration, Scoop, Whale Oil, Kiwiblog and LawTalk would be regarded as having a material influence on the public. Scoop is the third most visited news website in New Zealand. ${ }^{143}$ Its audience is also likely to rely on the independence of its content because the content is declared to have "no spin". ${ }^{144}$ Whale Oil is primarily a news blog that has over 3,000,000 non-unique hits per month. ${ }^{145}$ Kiwiblog is mainly a political blog that has over 500,000 non-unique hits per month and 9,000 registered commenters. ${ }^{146}$ LawTalk circulates 12,400 copies per issue with 23 issues per year. ${ }^{147}$ The audience of LawTalk includes influential people, such as members of the Judiciary. ${ }^{148}$ The audience size of these websites alone would mean that they have a material influence on the public. The content being primarily news adds to the potential for harm because of the important role of news in society.

\section{Commerciality}

A commercially oriented entity has more incentive to sacrifice standards and ethics than a non-commercial entity because doing so may lead to greater financial reward. Maintaining high standards and ethical reporting comes at a price: one must expend

\footnotetext{
${ }^{139}$ Big Picture Marketing Strategy and Research, above n 45, at [4.3].

${ }^{140}$ Finkelstein report, above n 100.

${ }^{141}$ At [11.67].

${ }^{142}$ At [11.67].

143 Scoop.co.nz, above n 134.

${ }^{144}$ Scoop.co.nz, above n 134.

${ }^{145}$ Cameron Slater, above n 135.

${ }^{146}$ David Farrar, above n 136.

${ }^{147}$ New Zealand Law Society, above n 137.

${ }^{148}$ New Zealand Law Society, above n 137.
} 
time and money to ensure one is in line with relevant standards and codes. Increased competition from non-traditional media is likely to decrease an entity's revenues. To maintain its profit margins, "ethical corner-cutting"149 may be used to reduce the operational costs associated with maintaining standards.

There are factors other than commerciality that provide incentives to breach standards and ethics. For example: standards of fairness may be breached in presenting an ideological view; or standards of accuracy may be breached by taking a sensationalistic perspective of an event. Quantifying ideology or sensationalism is difficult and subjective. A viewpoint may be ideological to some, yet normal to others and a sensational view may be a result of a lack of resources making due diligence impractical. In contrast, commerciality is more objective because it is only money that is being considered.

A commerciality analysis will be based on whether an entity is aiming to make a profit; aiming to make a profit will go towards the entity being required to join the Authority. The form of the entity, namely what it purports to be, is irrelevant; the focus will be on the substantive intention of the entity and whether it is seeking to profit from its operations. Factors such as eliciting excessive advertising or competitively remunerating staff, whilst not determinative, will be indicators of a profit-seeking entity. Whether in fact a profit is or is not made should not affect this analysis because intention to make a profit is the overarching concern. If an entity makes a loss in the pursuit of a profit, that may only incentivise it further to cut costs and in turn increase the likelihood of standards being breached.

Attempting to outline absolute values for measuring an entity's commerciality is futile because of the kaleidoscope of entities in the news media industry. Variables such as the size of the entity, the width of dissemination, the frequency of publication and sources of revenue would all affect a publisher's profitability. Instead, the panel will take a caseby-case approach to ascertain the true commercial intentions of an entity. Theoretically, being subject to a regulatory body will effectively be the trade-off an entity must make in order to make a commercial gain from being in the news media, all else being equal.

\section{Voluntary Membership}

News media entities that are not required to join NMSA under the matrix will have the option to voluntarily join. The only requirement will be that the entity meets the

\footnotetext{
${ }^{149}$ Law Commission, above n 115, at [6.109].
} 
definition of news media. As outlined earlier, the Law Commission set out criteria to define news media, ${ }^{150}$ but this paper will not adopt that definition because it is overly prescriptive.

News media must be defined more widely than the mandatory membership matrix for voluntarily membership to be operative. This paper recommends the following definition:

"Any organisation or individual that disseminates news to a sector of the public."

A sector of the public will defined widely as it is only included to ensure that the content is available in the marketplace of ideas to inform opinion. Other factors such as frequency of publication, width of dissemination and commerciality are not required. The danger of chilling news related expression by not giving entities the opportunity to join NMSA to use the associated benefits outweighs the potential for abuse of privileges by errant members. The demands of membership, namely providing funding, should deter excessive membership. The panel will have the discretion to revoke membership if it is of the opinion that an entity is misappropriating its membership. The onus will be on the applicant to prove to the panel that it fits within the aforementioned definition.

\section{Potential Objections to the Recommended Model}

\section{A Independence of NMSA}

A news media regulator being independent from the State and the news media industry is a preeminent concern, as expressed by a number of submissions to the Commission's Issues Paper. By having the Authority statutorily-based rather than self-regulated, it is arguable that the State will have, or be perceived to have, influence over the Authority. Analogies are made with the BSA which is thought to have a "significant degree of State control". ${ }^{151}$ State influence is undesirable because it may impede the news media's ability to impart impartial information and in turn to hold the State accountable for its actions.

This paper's recommended statutory base can be materially differentiated from the BSA's. The BSA relies on funding from the State to carry out its operations whereas

\footnotetext{
${ }^{150}$ Law Commission, above n 1, at [3.101].

${ }^{151}$ At [7.24].
} 
NMSA is wholly funded by the industry; state funding is only used for research purposes. "The State is a force in the setting of standards"" 152 for the BSA whereas the NMSA panel will be wholly responsible for setting standards. Moreover, the GovernorGeneral appoints the BSA's chairperson and board members, ${ }^{153}$ whereas appointment to NMSA's panel and adjudicatory body will be conducted by an independent group beyond State control. These differences ensure that the Authority is more independent from the State than the BSA.

A mixed membership model also ensures more independence from the news media industry than a voluntary membership model. As outlined earlier, a voluntary membership model has the fundamental risk of being undermined in breadth of coverage and funding if a major member withdraws or does not join the Authority. In contrast, the mixed membership guarantees funding from the entities that are required to join, which will not only remove financial and coverage risk but also any leverage a large entity may have over the Authority.

Furthermore, the assumption that State involvement compromises society's interest in an impartial news media can be countered by an argument of accountability. A democratic government can be held accountable by constituents exercising their democratic mandate. It is more difficult to hold the news media industry to account because there is no such mandate and with news media power and ownership being concentrated, there is no viable alternative source for general news.

Thus, the minimal statutory basis that this paper recommends will not compromise the Authority's independence. A similar level of statutory backing formed the Irish Press Council and its ombudsman stated that, "freedom of the press in Ireland is not undermined by statutory recognition of the country's press regulator". ${ }^{154}$

\section{B Compulsion is Not Necessary to Avoid Harm to the Public}

The mixed membership model is premised on the idea that requiring certain news media entities to be regulated is justified to limit, and provide redress for, harm to the public. It is arguable that an element of compulsion is not in fact necessary and that if news media entities do not voluntarily join a regulatory body, any ensuing harm can be addressed by existing laws and the market. However, many individuals will be deterred from taking

\footnotetext{
${ }^{152}$ Broadcasting Standards Authority "Submission to the Law Commission Issues Paper: The News Media Meets 'New Media': Rights, Responsibilities and Regulation in the Digital Age" at [35].

${ }^{153}$ Broadcasting Act, s26.

154 John Halliday "Leveson hears press freedom unharmed by Ireland's statutory regulation" The Guardian (13 July 2012) <www.theguardian.com>.
} 
legal action because of the time and resources required to do so, as well as the uncertainty of success.

With the internet being an ever-increasing source of news for consumers, there is a view that other consumers are able to hold the media to account for any breach of standards via comments on a webpage, blog or through social media. ${ }^{155}$ If this proposition holds, then an independent regulator is not necessary because the news media "will selfcorrect". ${ }^{156}$ This is an idealistic view and primarily deals with accuracy and fairness issues; ${ }^{157}$ privacy and decency issues will not addressed. ${ }^{158}$ The power imbalance between a large media entity and a disgruntled consumer may deter the latter from entering a public battle with the former. ${ }^{159}$ Moreover, information validity issues arise in that consumers may not know who to believe: a large media entity with resources, or an anonymous comment on a page.

It is true that regulation may be undermined because of jurisdictional issues with overseas based entities that disseminate news in New Zealand. Legal restrictions mean that those entities cannot be required to join the Authority even if they met the matrix of factors. However, this issue may be overstated in New Zealand because international entities seldom report New Zealand news to a New Zealand audience. Moreover, any international entities that do report New Zealand news in New Zealand tend to be large organisations that have efficient in-house complaints systems.

\section{Compulsion Will Chill Free Expression}

It is arguable that by compelling entities to join a regulatory body, their right to freedom of expression will be chilled and the public will not have a diverse and robust news media to accommodate their information needs. However, the proposed standards for NMSA are no more onerous than those of the BSA and PC. In fact, with the good taste and decency standard being left to the BSA, the proposed standards for NMSA are potentially more lenient than existing regulatory standards. ${ }^{160}$

\footnotetext{
${ }^{155}$ Law Commission, above n 115, at [6.44].

156 At [6.44].

${ }^{157}$ At $[6.46]$.

${ }^{158}$ At $[6.46]$.

159 At [6.46].

${ }^{160}$ At [7.57].
} 
From a journalist's point of view, the BSA already "sets the bar too high" 161 when interpreting its standards and codes. This suggests that expression will not be chilled simply by virtue of being subject to standards and codes but by the way those standards and codes are applied. This could be addressed by ensuring that the Authority only upholds decisions when it sees it as justifiable to limit the entity in question's right to freedom of expression. ${ }^{162}$ Periodic reviews of the Authority and its adjudication function can ensure consistency and a proper balancing of rights is being undertaken. Remedially, the Authority not having the power to award monetary damages provides less reason for expression to be chilled relative to the BSA where monetary damages are awarded. Thus, a mixed membership model will not chill expression any more than it may already be chilled by the BSA and PC; any further chilling of expression, relative to a voluntary membership model, will be justified.

\section{Conclusion}

The traditional platform-centric approach to media regulation is no longer tenable with the distinct line between broadcast and print media being blurred by mainstream media combining text and video via the internet. NMSA, the universal news media regulator recommended by the Law Commission, takes a content-centric approach to regulation.

This paper has concerns over the incentivised voluntary membership model endorsed by the Commission. It is arguable whether the Government would realistically premise the statutory exemptions and rights afforded to the news media upon being a member of NMSA. The benefits of a mediation service, brand advantage, avoiding the communications regime and access to public funding are overstated, depending on the entity. Moreover, having the option to join generates leverage for entities to potentially influence the formation and adjudications of the Authority.

The right to freedom of expression is an important right that should not be restricted without proper justification. News media conveys information of utmost importance to society and consequently significant harm to individuals and the public can result if standards are not followed. Thus, like other professions, some regulation of the news media is necessary.

\footnotetext{
161 Colin Peacock "Principles and Pragmatism: An Assessment of Broadcasting Standards Authority Decisions from a Journalist's Perspective" (Broadcasting Standards Authority, Wellington, 2009) at 1112.

${ }^{162}$ Price, above n 84 .
} 
This paper recommends a mixed membership model that analyses an entity's influence on the public and its commerciality to ascertain whether it should be required to join NMSA. The minimalistic statutory foundation recommended by this paper will increase the Authority's overall independence and a wider definition of news media allows a greater range of entities to join NMSA. 


\section{Bibliography}

A Cases

Campbell v MGN Ltd [2004] 2 AC 457 (HL).

B Legislation

$1 \quad$ New Zealand

Broadcasting Act 1989.

Care of Children Act 2004.

Children, Young Persons, and Their Families Act 1989.

Criminal Procedure Act 2011.

Fair Trading Act 1986.

Family Courts Act 1980.

Family Proceedings Act 1980.

Films, Videos, and Publications Classification Act 1993

Health Practitioners Competence Assurance Act 2003.

Lawyers and Conveyencers Act 2006.

New Zealand Bill of Rights Act 1990.

New Zealand Institute of Chartered Accountants Act 1996.

Privacy Act 1993.

Social Workers Registration Act 2003.

\section{$2 \quad$ Ireland}

Defamation Act (Ireland) 2009.

\section{Denmark}

The Media Liability Act (Denmark) 1998.

\section{Books and Chapters in Books}

Claudia Geiringer and Steven Price "Moving from Self-Justification to Demonstrable Justification - the Bill of Rights and the Broadcasting Standards Authority" in Jeremy Finn and Stephen Todd Law, Liberty, Legislation (LexisNexis, Wellington, 2008) 295

Elizabeth Longworth and Tim McBride The Privacy Act: A Guide (GP Publications, Wellington, 1994). 
Eric Barendt Freedom of Speech (Oxford University Press, Oxford, 1985).

Fred Siebert, Theodore Peterson and Wilbur Schramm Four Theories of the Press (University of Illinois Press, Illinois, 1956).

Frederick Schauer Free Speech: A Philosophical Enquiry (Cambridge University Press, Cambridge, 1982).

Lara Fielden Regulating for Trust in Journalism: Standards regulation in the age of blended media (Reuters Institute for the Study of Journalism, Oxford, 2011).

William Hocking Freedom of the Press: A Framework of Principle (The University of Chicago Press, Chicago, 1947).

Wojciech Sadurski Freedom of Speech and Its Limits (Kluwer Academic Publishers, Dordcrecht (The Netherlands), 1999).

D Journal Articles

Gavin Ellis "Different Strokes for Different Folk: Regulatory Distinctions in New Zealand Media" (2005) 11(2) Pacific Journalism Review 63.

Lesley Hitchens "Media Regulatory Frameworks in the Age of Broadband: Securing Diversity" (2011) 1 Journal of Information Policy 217.

Peter McLuskie "The FTA: Alternative to Defamation" [2001] NZLJ 96.

E Parliamentary Materials

$1 \quad$ Hansard

(1 July 1986) 472 NZPD 2499.

$2 \quad$ Select Committee Reports

Cabinet Social Policy Committee Harmful Digital Communications: Cabinet Social Policy Committee Paper.

3 Rules

Rules of the Parliamentary Press Gallery 2011. 
F $\quad$ Articles and Reports

Big Picture Marketing Strategy and Research Public Perception of News Media Standards and Accountability in New Zealand (Big Picture Research, Auckland, 2012).

Broadcasting Standards Authority BSA Annual Report 2012 (Broadcasting Standards Authority, Wellington, 2012).

Colin Peacock "Principles and Pragmatism: An Assessment of Broadcasting Standards Authority Decisions from a Journalist's Perspective" (Broadcasting Standards Authority, Wellington, 2009)

Law Commission Harmful Digital Communications: The adequacy of the current sanctions and remedies (NZLC Ministerial Briefing Paper, 2012).

Law Commission Review of the Privacy Act 1993: Review of the Law of Privacy Stage 4 (NZLC R123, 2011)

Law Commission The News Media Meets 'New Media': Rights, Responsibilities and Regulation in the Digital Age (NZLC R128, 2013).

Law Commission The News Media Meets 'New Media': Rights, Responsibilities and Regulation in the Digital Age (NZLC IP27, 2011).

New Zealand Press Council $40^{\text {th }}$ Report of the New Zealand Press Council (New Zealand Press Council, Wellington, 2012).

Steven Price "The BSA and the Bill of Rights: A Practical Guide" (Broadcasting Standards Authority, Wellington, 2012).

The Hon R Finkelstein QC Report of the Independent Inquiry into the Media and Media Regulation (Report to the Minister for Broadband, Communications and the Digital Economy, Canberra, 2012).

The Rt Hon Lord Justice Leveson Report of An Inquiry into the Culture, Practice and Ethics of the Press (The Stationary Office, London, 2012). 


\section{G Submissions \\ $1 \quad$ Academic}

Gavin Ellis submission to Law Commission The News Media Meets 'New Media': Rights, Responsibilities and Regulation in the Digital Age.

Ross Johnston submission to Law Commission The News Media Meets 'New Media': Rights, Responsibilities and Regulation in the Digital Age 12 March 2012.

Professor Ursula Cheer submission to Law Commission The News Media Meets 'New Media': Rights, Responsibilities and Regulation in the Digital Age.

$2 \quad$ Media

Allied Press submission to Law Commission The News Media Meets 'New Media': Rights, Responsibilities and Regulation in the Digital Age 6 March 2012.

APN News Media submission to Law Commission The News Media Meets 'New Media': Rights, Responsibilities and Regulation in the Digital Age March 2012.

MediaWorks submission to Law Commission The News Media Meets 'New Media': Rights, Responsibilities and Regulation in the Digital Age 11 April 2012.

Television New Zealand and others submission to Law Commission The News Media Meets 'New Media': Rights, Responsibilities and Regulation in the Digital Age 4 April 2012.

\section{Regulator}

Advertising Standards Authority submission to Law Commission The News Media Meets 'New Media': Rights, Responsibilities and Regulation in the Digital Age March 2012.

Broadcasting Standards Authority submission to Law Commission The News Media Meets 'New Media': Rights, Responsibilities and Regulation in the Digital Age 12 March 2012. 
New Zealand Press Council submission to Law Commission The News Media Meets

'New Media': Rights, Responsibilities and Regulation in the Digital Age March 2012.

$4 \quad$ Individual

David Farrar submission to Law Commission The News Media Meets 'New Media': Rights, Responsibilities and Regulation in the Digital Age.

\section{H Dissertations}

Matthew Dearing "Taming the Wild West - A Framework for Regulating and Applying Broadcasting Standards to Internet Content in New Zealand" (LLM Dissertation, Victoria University of Wellington, 2010).

I Internet Resources

Allison Jones "Sun Media ditches press council, citing issues with "political correctness"” The Toronto Star (13 July 2011)<www.thestar.com>.

Bill Rosenberg "News Media Ownership in New Zealand: Who Owns What?" (13 September 2008) <www.converge.org.nz>.

Cameron Slater “About” Whale Oil Beef Hooked <www.whaleoil.co.nz>.

David Farrar “About Kiwiblog” Kiwiblog <www.kiwiblog.co.nz>.

Don McCurdy “Executive Director's 2012 Report” Ontario Press Council (5 January 2013) <www.ontpress.com>.

Hacked Off "What's wrong with the press bosses' latest regulation proposal?" (12 July 2013) <www.hackinginquiry.org>.

Ian Burrell "Desmond withdraws his titles from press complaints regulation" The Independent (12 January 2011) <www.theindependent.co.uk>.

John Halliday "Leveson hears press freedom unharmed by Ireland's statutory regulation" The Guardian (13 July 2012) <www.theguardian.com>.

New Zealand Law Society "LawTalk"<www.lawsociety.org.nz>. 
New Zealand Parliament "The Parliamentary Press Gallery" (3 May 2013) $<$ www.parliament.nz $>$.

Nuno Garoupa "Regulation of Professions in the US and Europe: A Comparative Analysis (April 2004) The Berkeley Electronic Press <www.law.bepress.com>.

NZ On Air "Funding Decisions" <www.nzonair.govt.nz>.

Online Media Standards Authority "The Rules of the Online Media Standards Authority Incorporated" <www.omsa.co.nz>.

Ontario Press Council "Constitution" (2010) <www.ontpress.com>.

Regan “TV Ratings: 6 September 2013” (7 September 2013) Throng $<$ www.throng.co.nz>.

Scoop.co.nz "Introducing Scoop.co.nz"<www.scoop.co.nz>.

$J \quad$ Other Resources

Philip Ward "Press Regulation - the Debate" (House of Commons Library Note SN/HA/6357, 2012).

Media Regulation Roundtable Final Proposal For Future Regulation Of The Media: A Media Standards Authority (Media Regulation Roundtable, 2012). 


\section{Word Count}

The text of this paper (excluding cover page, contents page, abstract, keywords, footnotes and bibliography) is 7,990 